\title{
等昼光率網目について
}

\author{
專門会員 藤原 義輝* 正会員 大谷 義彥*
}

\section{On the Diagram of Iso-daylight-factor}

\author{
Yoshiteru Fujiwara (Fellow Member), Yoshihiko Otani (Member)
}

(College of Industrial Technology Nihon Univ.)

\begin{abstract}
The improved Iso-daylight-facor Diagrams are described for calculating the direct daylight-factor by using the images of solid angle projection diagram, convex mirror and fish-eye lens.

We devised two types of the diagrarm for each of the above three images and were able to use one of them according to shape of light source.

We compared theoretical values to experimental values about the direct daylight-factor of some examples, so made sure to put these methods to practical use.
\end{abstract}

\section{1. 緒言}

採光設計に拈ける明るさの基準としては昼光率が使用 される. 昼光による照度は季節や時刻に伴う太陽高度の 変化, 天候などによって変動する．そこで光源の変動の 影響を受けずに，しかも明るさの指標となるものとして 昼光率肪用いられる1).

昼光率の測定法あるいは算定法については, 過去に数 多くの報告がなされて拈り，実際に用いられているるの もある.これらの方法を大別すると，(1) 直接計算する方 法(たと光ば立体角投射の法則)，(2) 算定図または表によ る方法 (たと壳ば立体角投射図 ${ }^{2}$, 小木曾の図4), (3) 分 度器による方法 (たと兄ば BRS 分度器 ${ }^{8}$ ), (4) 写真機に よる方法 (たと光ば立体角投射写真機5) Globo scope ${ }^{\text {()) }}$ ) になる。

本論に述べる等昼光率網目 は, 立体角投射図, 凸面 鏡, 魚眼カメラより得られる光源の投影像から直接昼光 率の值を算定しょうとするものであり, 容易に, 迅速 に, かつ正確に求めることを目標に試みたものである.

\section{2. 立体角投射図に対する網目 ${ }^{9 \sim 11)}$}

\section{1 立体角投射図}

立体角投射図は，図１亿示すように立体角投射の法則
を応用して，水平角扰よび鉛直角の網目を描いたもの で, 水平角 $\varphi$ はとのまま, 鉛直角 $\theta$ を $(1-\cos \theta)$ に とってある.たと充ば図 2 のよらに光源 $S$ の境界線上 の諸点 A，B，C，D相当する立体角投射 図上の点 $\mathrm{a}^{\prime}, \mathrm{b}^{\prime}, \mathrm{c}^{\prime}, \mathrm{d}^{\prime}$ をとって, これらを結べば, 光源の立体 角投射面積 $S_{o}$ が得られる. したがって, P点に和ける 直接照度 $E_{d}$ は光源の輝度 $B$ が一定ならば, 立体角投 射の法則により

$$
E_{d}=\int_{S_{o}} B d S_{o}=B S_{0}
$$

で与兄られる。またこのときの全天空照度 $E_{s}$ は

$$
E_{s}=B \overline{S_{0}}
$$

となり， $\overline{S_{o}}$ は全天空の立体角投射面積で, 全円の面積 である.

直接昼光率は, ある点の直接照度とその点の全天空照 度との比で示されるから, 上記の場合の直接昼光率 $D_{d}$ は

$$
D_{d}=\frac{E_{d}}{E s} \times 100=\frac{B S_{0}}{B \overline{S_{0}}} \times 100=\frac{S_{o}}{\overline{S_{o}}} \times 100(\%) \cdots(3)
$$

となり, 立体角投射面積の比で与兄られることがわか る.

\section{2 網目の作成}

(3)式により立体角投射面積が昼光率の值に比例するこ とは明らかである、したがって, 等昼光率網目を得るた 


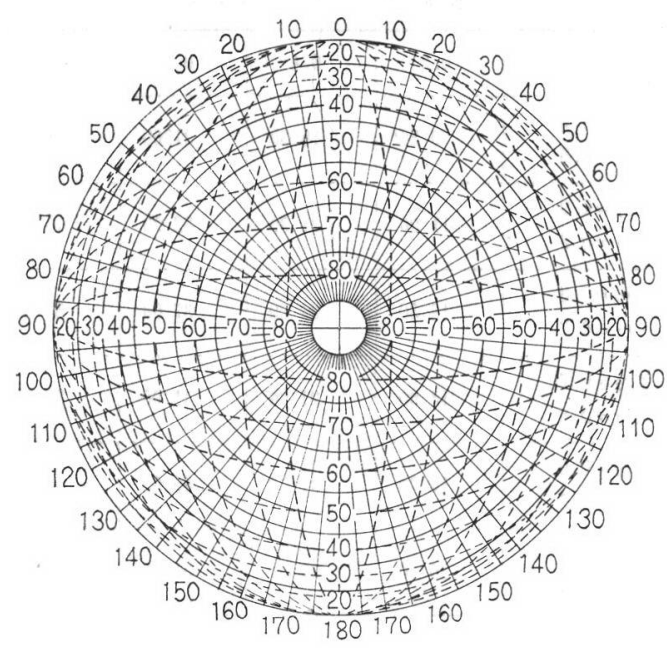

図 1 立体角投射図

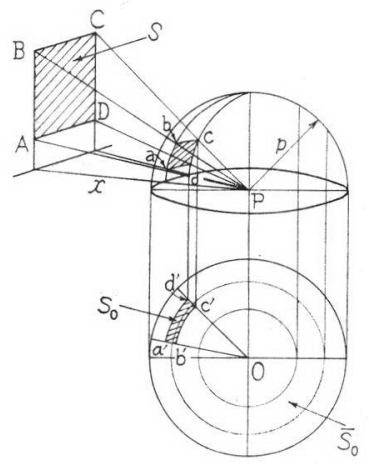

図 2 立体角投射面積

めには，全円を等面積の網目となるように分割すれば， おのおのの網目は等しい昼光率を示すことになる，そこ

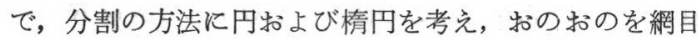
S-I拈よび網目 S-II として以下述べる.

\section{(a) 網 目 S-I}

半径 $r=1$ の円を考克, 同心円 (緯度) により十等分 する、すなわち図 3 に扮いて, 全円の面積を $\bar{S}_{o}$, 斜線 を施した同心円の半径を $r_{o}$ ，その面積を $S_{o}$ とすれば，

$$
S_{o} / \overline{S_{o}}=\pi r_{0}^{2} / \pi \times 1^{2}=r_{0}^{2}
$$

であるから，

$$
r_{0}{ }^{2}=0.1,0.2 \cdots \cdots, 0.9
$$

となる $r_{0}$ を求め, 半径 $r_{0}$ の同心円で分割する.

次に中心ょり $18^{\circ}$ 間隔の放射線（経度）で細分割し て網目を完成させる，このようにしてできた緯度, 経度 とよって囲まれる網目は打の特の $\bar{S}_{0} / 200$ となり，すべ て $0.5 \%$ の昼光率を示していることになる. 表 1 に半 径 $r_{0}$ の値招よび $r_{0}$ に対する天頂角 $\theta$ の值を示す.

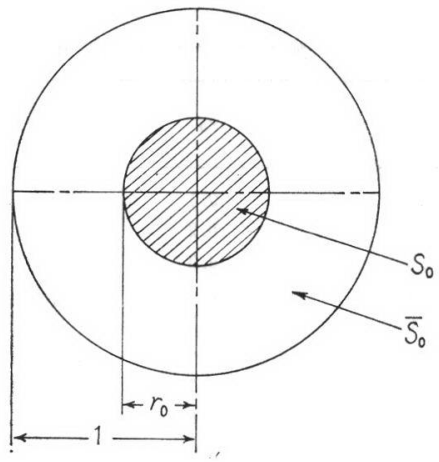

図 3 立体角投射図に対する網目の 作成 (S-I)

表 1 半径と天頂角 (S-I)

\begin{tabular}{c|c|c}
\hline$\frac{S_{0}}{\overline{S_{0}}}$ & $r_{0}$ & $\theta$ \\
\hline 0.1 & 0.316 & $18^{\circ} 26^{\prime}$ \\
0.2 & 0.447 & $26^{\circ} 34^{\prime}$ \\
0.3 & 0.548 & $33^{\circ} 13^{\prime}$ \\
0.4 & 0.632 & $39^{\circ} 14^{\prime}$ \\
0.5 & 0.707 & $45^{\circ} 00^{\prime}$ \\
0.6 & 0.775 & $50^{\circ} 46^{\prime}$ \\
0.7 & 0.835 & $56^{\circ} 47^{\prime}$ \\
0.8 & 0.894 & $63^{\circ} 26^{\prime}$ \\
0.9 & 0.949 & $71^{\circ} 34^{\prime}$ \\
1.0 & 1.000 & $90^{\circ} 00^{\prime}$ \\
\hline
\end{tabular}

\section{(b) 網 目 S-II}

図 4 の上うに半径 $r=1$ の 円内に長径が円の半径と 等しく, 短径が $r_{o}$ の楕円を考光る. 円の面積を $\overline{S_{o}}$, 棈 円の面積を $S_{0}$ とすれば

$$
S_{o} / \overline{S_{o}}=\pi r_{0} / \pi \times 1=r_{0}
$$

であるから

$$
r_{0}=0.1,0.2 \text {. }
$$

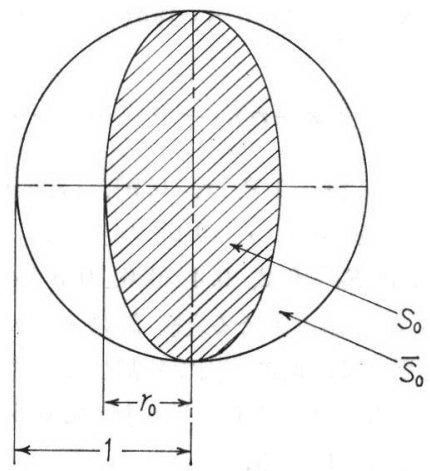

图 4 立体角投射図に対する網目の 作成 (S-II)

を短径とする楕円で分割すれば，すべて等面積となる. このときの各 $r_{0}$ に対する天頂角 $\theta$ の值を表 2 飞示す. 次に細分割であるが，図 5 のように半径 $r=1$ の円 
表 3 細分割に用いる角度 $(\varphi)$

表 2 短径と天頂角 (S-II)

\begin{tabular}{c|c|c}
\hline$\frac{S_{0}}{\overline{S_{0}}}$ & $r_{0}$ & $\theta$ \\
\hline 0.1 & 0.1 & $5^{\circ} 44^{\prime}$ \\
0.2 & 0.2 & $11^{\circ} 32^{\prime}$ \\
0.3 & 0.3 & $17^{\circ} 27^{\prime}$ \\
0.4 & 0.4 & $23^{\circ} 35^{\prime}$ \\
0.5 & 0.5 & $30^{\circ} 00^{\prime}$ \\
0.6 & 0.6 & $36^{\circ} 52^{\prime}$ \\
0.7 & 0.7 & $44^{\circ} 26^{\prime}$ \\
0.8 & 0.8 & $53^{\circ} 08^{\prime}$ \\
0.9 & 0.9 & $64^{\circ} 09^{\prime}$ \\
1.0 & 1.0 & $90^{\circ} 00^{\prime}$ \\
\hline
\end{tabular}

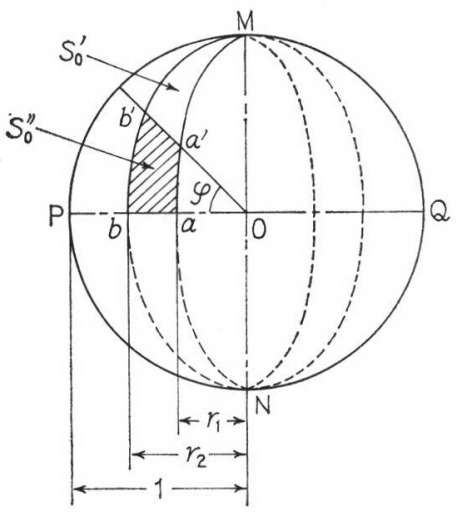

図 5 立体角投射図に対する網 目の作成( S-II：細分割)

に内接する短径 $r_{1} ， r_{2}$ の楕円を考兄る. この二つの棈 円と短径 $\overline{\mathrm{PO}}$ とで囲まれる面積を $S_{o}^{\prime}$ とし，また短径 $\overline{\mathrm{PO}}$ から角 $\varphi$ の直線によってできる斜線部分の面積を $S_{0}^{\prime \prime}$ とすれば,

$$
S_{o}^{\prime \prime} / S_{o}^{\prime}=\frac{1}{2}\left\{r_{2} \tan ^{-1}\left(r_{2} \tan \varphi\right)-r_{1} \tan ^{-1}\left(r_{1} \tan \varphi\right)\right\} /
$$

$$
\frac{1}{4} \pi\left(r_{2}-r_{1}\right)
$$

であるから, $\left[r_{2}=1.0, r_{1}=0.9\right],\left[r_{2}=0.9, r_{1}=0.8\right]$

…........ $\left[r_{2}=0.1, r_{2}=0.0\right]$ のときた

$$
S_{o}^{\prime \prime} / S_{o}^{\prime}=0.2,0.4,0.6,0.8
$$

となる $\varphi$ の值を求めると表 3 の上らになる. これら の值を用いて，前に楕円で分割したものを，さらに細分 割すれば網目はでき上がり,すべて $0.5 \%$ の昼光率を示 していることになる.

\section{3.凸面鏡に対する網目}

\section{1 凸 面 鏡}

凸面鏡は，底面の中心を含む垂直断面の切り口が放物 線になるものを用いた。すなわち図 6 のように, 底面

\begin{tabular}{r|r|r|r|r}
\hline$r_{2} ; r_{1}{ }^{\prime \prime} / S^{\prime}$ & 0.2 & 0.4 & 0.6 & 0.8 \\
\hline$\left[\begin{array}{l}r_{2}=1.0 \\
r_{1}=0.9\end{array}\right.$ & $9^{\circ} 30^{\prime}$ & $19^{\circ} 30^{\prime}$ & $31^{\circ} 00^{\prime}$ & $45^{\circ} 00^{\prime}$ \\
\hline$\left[\begin{array}{l}r_{2}=0.9 \\
r_{1}=0.8\end{array}\right.$ & 1100 & 2130 & 3300 & 4830 \\
\hline$\left[\begin{array}{l}r_{2}=0.8 \\
r_{1}=0.7\end{array}\right.$ & 1230 & 2430 & 3700 & 5130 \\
\hline$\left[\begin{array}{l}r_{2}=0.7 \\
r_{1}=0.6\end{array}\right.$ & 1400 & 2700 & 4100 & 5600 \\
\hline$\left[\begin{array}{l}r_{2}=0.6 \\
r_{1}=0.5\end{array}\right.$ & 1600 & 3130 & 4600 & 5930 \\
\hline$\left[\begin{array}{l}r_{2}=0.5 \\
r_{1}=0.4\end{array}\right.$ & 2030 & 3700 & 5130 & 6500 \\
\hline$\left[\begin{array}{l}r_{2}=0.4 \\
r_{1}=0.3\end{array}\right.$ & 2500 & 4430 & 5830 & 6930 \\
\hline$\left[\begin{array}{l}r_{2}=0.3 \\
r_{1}=0.2\end{array}\right.$ & 3230 & 5330 & 6630 & 7530 \\
\hline $\begin{array}{l}r_{2}=0.2 \\
r_{1}=0.1\end{array}$ & 4630 & 6600 & 7530 & 8130 \\
\hline $\begin{array}{l}r_{2}=0.1 \\
r_{1}=0.0\end{array}$ & 7300 & 8230 & 8600 & 8800 \\
\hline
\end{tabular}

半径を $R$, 中心を $\mathrm{O}$, 天頂角 $\theta$ の 鏡面上の一点を $\mathrm{P}$ と すれぱ，焦点半径 $r(=\overline{\mathrm{OP}})$ か

$$
r=\frac{R}{1+\cos \theta} \cdots \cdots \cdots \cdots \cdots \cdots \cdots \cdots \cdots \cdots \cdots \cdots \cdots \cdots \cdots \cdots \cdots \cdots \cdots \cdots \cdots
$$

で与壳られる放物面鏡である.したがって，中心Oは放 物面鏡の焦点之なり, 中心 $\mathrm{O}$ 亿向から天空内のすべての 光線は鏡面 $\mathrm{G}$ で正反射して, 底面に垂直な平行光線とな る. また, 天頂角 $\theta$ にある光源 $\Delta S$ の投影像 $\Delta S^{\mathbf{2}}$ は, 底面上の $\mathrm{P}^{\prime}$ に生じ, この像の中心 $\mathrm{O}$ からの距離 $R^{\prime}(=$ $\overline{\left.\mathrm{OP}^{\prime}\right)}$ は,

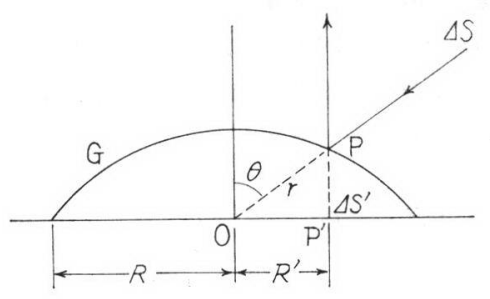

図 6 放物面鏡による投影像

$$
R^{\prime}=R \sin \theta / 1+\cos \theta=R \tan \frac{\theta}{2}
$$

である.

われわれの使用した放物面鏡は, 底面半径 $R=10(\mathrm{~cm})$ である.これを測定面に置き, 中心 0 上り高さ $h=1(\mathrm{~m})$ 
のところに写真機を設置して, 鏡面の反射像を撮影する ことにより，天空内にある被写体の平射図が得られる.

\section{2 網目の作成}

さきに求めた立体角投射図に対する網目は，等昼光率 の光源による投影であると考学られるから, 凸面鏡に対 する網目を作成する場合には, 上記光源の凸面鏡による 投影図を求めればよい.

立体角投射図に対する網目に郝ける. 円分割 $(S-I)$ および棈円分割（S-II）に対応するものを，ここでは 網目 P-I 扣よび網目 P-II として, その作成方法を述 ベる.

\section{(a) 網 目 P-I}

網目 S-I に拈ける同心円をたと六ば.水平円形光源 の投影と考劣て，この光源の凸面鏡による投影像を求め る.図 7 に执いて, 光源 $S$ の凸面鏡 $\mathrm{G}$ にる投影を $S^{\prime}$ とすれば，立体角投射図の場合と同様に円となる．この 場合の半径 $R^{\prime}$ は(11)式により計算でき, 天頂角 $\theta$ の值 は表 1 を用いればよい. 計算結果を表 4 に示す.した
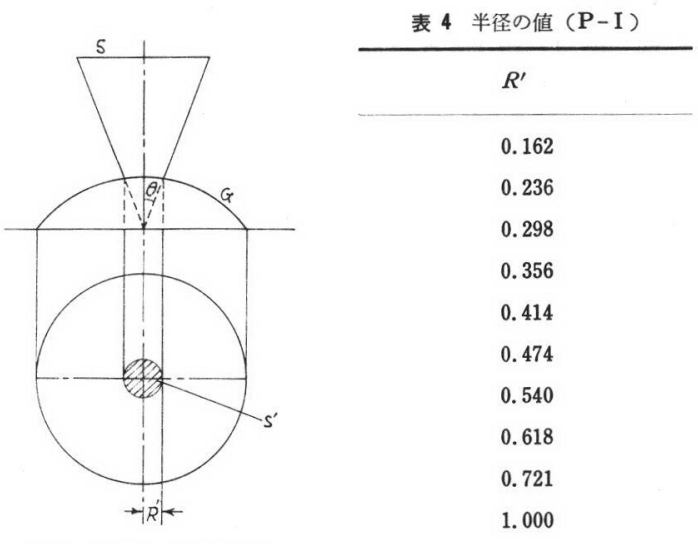

図 7 凸面鏡に対する網目 の作成 (P-I)

がって, $R^{\prime}$ を半径とする同心円と, 中心より $18^{\circ}$ 間隔 の放射線で分割すれば網目はでき上がる.この場合，各 網目の面積は等しくないが，昼光率ではすべて $0.5 \%$ を 示すことになる.

\section{（b）網 目 P-II}

網目 S-II に扣ける棈円は, 立体角投射の法則により 測定面に平行な無限直線の投影である. いま図 8 のよ

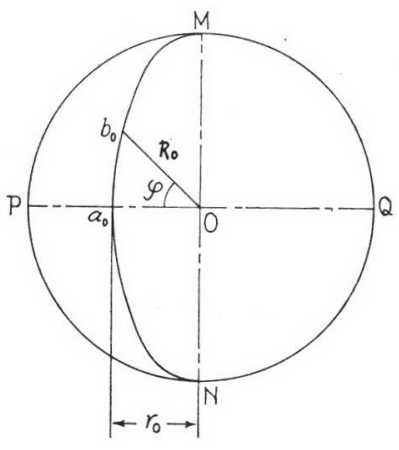

図8 無限直線の投影 (立体角投射の法則)

らに長径 1 , 短径 $r_{0}$ の棈円を考学て, 短径より $\varphi$ 傾 いた棈円の動径を $R_{0}$ とすれば

$$
R_{0}=\frac{1^{2} \times r_{0}^{2}}{1^{2} \times \cos ^{2} \varphi+r_{0}^{2} \sin ^{2} \varphi}
$$

であり,このときの無限直線に対する天頂角 $\theta$ は

$$
\theta=\sin ^{-1} R_{0}
$$

である。

上記無限直線の凸面鏡に対する投影が図 9 のよ5に 弓形となったとすれば, 短径より

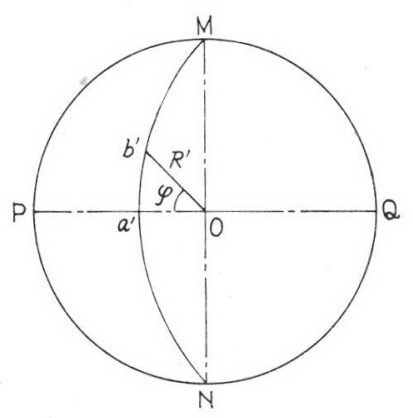

图 9 凸面鏡に対する網目の 作成 (P-II)

\begin{tabular}{|c|c|c|c|c|c|c|c|c|c|}
\hline$\rho$ & $R_{1}^{\prime}$ & $R_{2}^{\prime}$ & $R^{\prime}{ }_{3}$ & $R_{4}^{\prime}$ & $R^{\prime}{ }_{5}$ & $R^{\prime}{ }_{6}$ & $R^{\prime} 7$ & $R_{8}^{\prime}$ & $R_{9}^{\prime}$ \\
\hline 0 & 0.050 & 0.100 & 0.153 & 0.209 & 0.268 & 0.333 & 0.408 & 0.500 & 0.627 \\
\hline 10 & 0.051 & 0.102 & 0.155 & 0.212 & 0.272 & 0.338 & 0.413 & 0.505 & 0.631 \\
\hline 20 & 0.053 & 0.106 & 0.162 & 0.221 & 0.281 & 0.350 & 0.427 & 0.518 & 0.644 \\
\hline 30 & 0.058 & 0.116 & 0.175 & 0.238 & 0.303 & 0.373 & 0.451 & 0.543 & 0.664 \\
\hline 40 & 0.065 & 0.131 & 0.197 & 0.265 & 0.335 & 0.408 & 0.488 & 0.579 & 0.695 \\
\hline 50 & 0.078 & 0.155 & 0.231 & 0.307 & 0.383 & 0.460 & 0.540 & 0.628 & 0.735 \\
\hline 60 & 0.099 & 0.194 & 0.288 & 0.375 & 0.457 & 0.535 & 0.613 & 0.693 & 0.787 \\
\hline 70 & 0.144 & 0.276 & 0.389 & 0.487 & 0.570 & 0.643 & 0.710 & 0.775 & 0.848 \\
\hline 80 & 0.268 & 0.462 & 0.590 & 0.678 & 0.742 & 0.795 & 0.838 & 0.878 & 0.919 \\
\hline
\end{tabular}

表 5 動 径 $の$ 值 (P-II) 
$R^{\prime}$ は(13)式の $\theta$ の值を(11)式に代入すれば求めることが できる.

したがって，図面を描くのに必要なだけ $\varphi$ をとり, 表 2 に示した $r_{0}$ の值を用いて計算すれば， $R^{\prime}$ の值は 表 5 のようになる。この結果により，立体角投射図を 凸面鏡の投影図とすることができる.

次に細分割するのであるが，測定面に垂直な線は，立 体角投射図に预いても，末た凸面鏡の投影図に执いても 同じょうに投影するから，表 3 の值をそのまま用いれば よい。

\section{4. 魚眼レンズに対する網目 ${ }^{12 ~ 14)}$}

\section{1 魚眼カメラ}

日本光学製の魚眼レンズ (Fish-eye-NIKKOR) を装 てんしたカメラを用いて, 画角 $180^{\circ}$ の半球全体の物体 を撮影する.この魚眼レンズは図 10 に示すように, 天 空内にある光源 $\Delta S$ の天頂角を $\theta$ とし, その $\mathrm{P}^{\prime \prime}$ に生 じた像点黑 $\Delta S^{\prime \prime}$ の光軸からの距離を $R^{\prime \prime}$ とすれば
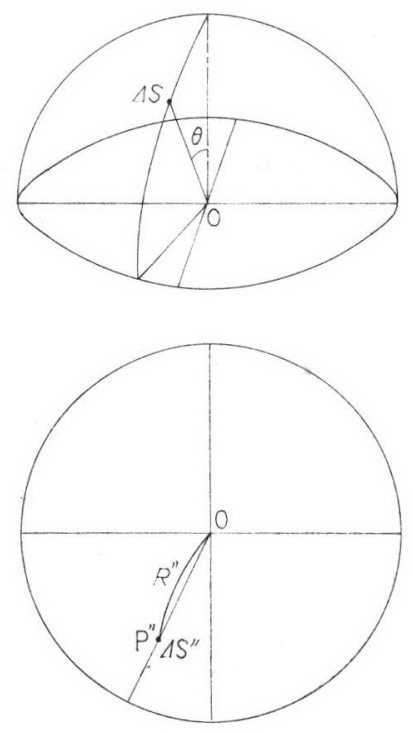

図 10 魚眼レンズによる投影像
$R^{\prime \prime}=C \theta$ (14)

（ただし，Cは比例定数）

で与兄られる等距離射影の性質を有している.

\section{2 網目の作成}

魚眼レンズに対する網目る，さきに求めた凸面鏡の方 法と同様に考光ればよい.

\section{(a) 網 目 F-I}

表 1 亿示した天頂角 $\theta$ の值を(14)式に代入して $R^{\prime \prime}$ を 求めると, 表 6 のようになる.

表 6 半径の值 (F-I)

\begin{tabular}{l||c}
\hline$R^{\prime \prime}$ & $R^{\prime \prime}$ \\
\hline 0.221 & 0.564 \\
0.296 & 0.630 \\
0.369 & 0.705 \\
0.436 & 0.795 \\
0.500 & 1.000 \\
\hline
\end{tabular}

したがって，R" $R^{\prime \prime}$ 半径とする同心円と.中心より $18^{\circ}$ 間隔の放射線で分割すればよい。

\section{(b) 網 目 F-II}

測定面に平行な無限直線を考光て，魚眼レンズによる 投影が図11のような弓形となったとする，短径より

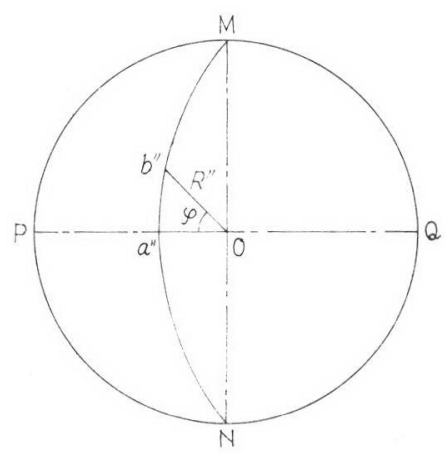

図 11 魚眼レンズに対する網目 の作成 (F-II)

$\varphi$ 傾いた動径 $R^{\prime \prime}$ は(14)式により求めら机るから, さき 飞述べた凸面鏡の場合と同様に(12)，(13)式を用いて計算す れぱ表 7 の結果を得る. 細分割も同様に表 3 の值を用

表 7 動 径 $の$ 值 (F-II)

\begin{tabular}{r|c|c|c|c|c|c|c|c|c}
\hline$\varphi$ & $R^{\prime \prime}{ }_{1}$ & $R^{\prime \prime}{ }_{2}$ & $R^{\prime \prime}{ }_{3}$ & $R^{\prime \prime}{ }_{4}$ & $R^{\prime \prime}{ }_{5}$ & $R^{\prime \prime}{ }_{6}$ & $R^{\prime \prime}{ }_{7}$ & $R^{\prime \prime} 8$ & $R^{\prime \prime}{ }_{9}$ \\
\hline 0 & 0.064 & 0.128 & 0.194 & 0.262 & 0.333 & 0.410 & 0.497 & 0.590 & 0.713 \\
10 & 0.065 & 0.130 & 0.197 & 0.265 & 0.337 & 0.414 & 0.498 & 0.595 & 0.717 \\
20 & 0.068 & 0.136 & 0.206 & 0.276 & 0.351 & 0.429 & 0.513 & 0.609 & 0.728 \\
30 & 0.074 & 0.147 & 0.222 & 0.297 & 0.374 & 0.454 & 0.539 & 0.633 & 0.747 \\
40 & 0.083 & 0.166 & 0.248 & 0.330 & 0.411 & 0.493 & 0.578 & 0.668 & 0.773 \\
50 & 0.099 & 0.196 & 0.289 & 0.380 & 0.466 & 0.549 & 0.630 & 0.729 & 0.808 \\
60 & 0.126 & 0.247 & 0.357 & 0.457 & 0.546 & 0.626 & 0.700 & 0.772 & 0.849 \\
70 & 0.182 & 0.343 & 0.473 & 0.577 & 0.660 & 0.728 & 0.786 & 0.840 & 0.896 \\
80 & 0.334 & 0.551 & 0.679 & 0.759 & 0.814 & 0.855 & 0.888 & 0.918 & 0.955 \\
\hline
\end{tabular}


いればよい。

\section{5. 等㡺光率網目の使用}

以上のように, 立体角投射図, 凸面鏡および魚眼レン ズに対する等昼光率網目の作成方法について述べた. お のおのについて I および II 型の 2 種類あるが, 使用の便 宜を考光て一つにまとめた。図 12 に立体角投射図に対 する網目 $(S-I, I I)$, 図 13 に凸面鏡に対する網目

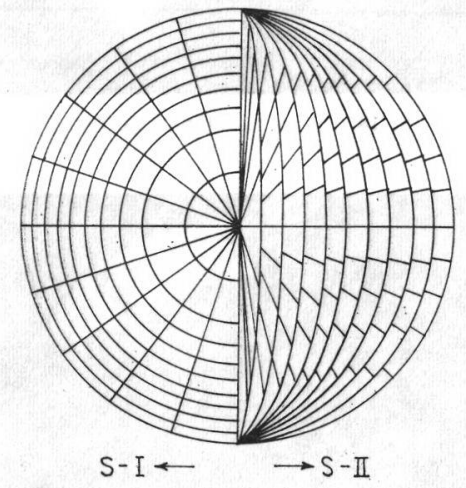

図 12 立体角投射図に対する等昼光率網目

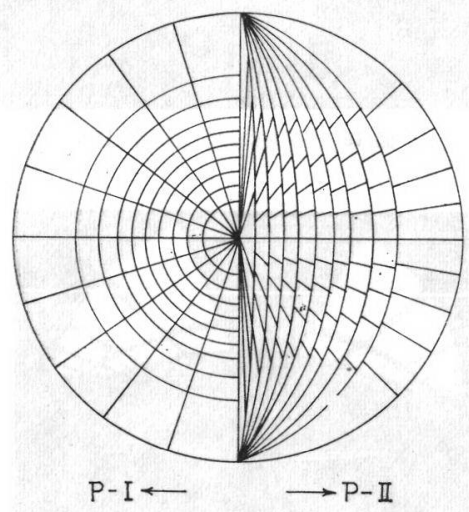

図 13 凸面鏡に対する等昼光率網目

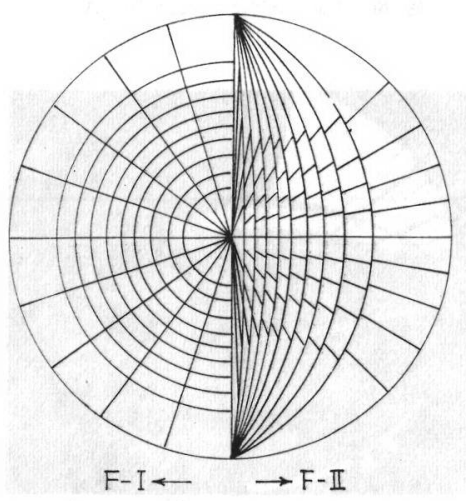

図 14 魚眼レンズに対する等昼光率網目
（P-I，II）抽び図 14 に魚眼レンズに対する網目 (F-I， II）を示す.

立体角投射図に対する網目は, 光源の輪郭を記入した 同一直径の立体角投射図（図 1) 飞重ね合わせて，網目 の数をかぞえれば，直ちに昼光率の值を知ることができ る.したがって，従来行なわれてきたプラニメータなど によって面積比を求める方法より簡易に昼光率算定がで きる. この場合, 光源の形が矩形, 円形等純幾何学的形 態でないと，立体角投射図への記入が困難であるから， 拈のづとその利用には限度がある. しかし, 立体角投射 写真機5)，OTスコープ15)などは全天空の立体角投射像 を直接得ることができるから，それらに応用すれば便利 である。

凸面鏡および魚眼レンズに対する網目は，それぞれの 方法により撮影した写真を同一直径に引き伸ばして, 重 ね合わせればよい。

おのおのに拈けるIおよび【型を使用する場合, 前者 については, 水平円形光源 (たと光ば, 円形天空), 円 筒形室の空, 後者は鉛直矩形光源（たとえば，鉛直矩形 空，鋸歯状密）の昼光率算定に用いるとよい，また投射 図に括ける光源の輪郭が上記形状にあてはまらないよう な複雑な場合でも, 多少の誤差を容認するならば，同様 に求めることができる，以上述べたような，網目を用い て昼光率を算定する方法は，内外に数例を見ることがで きる。

これらのらち，極射影カメラに用いる等投射率網目

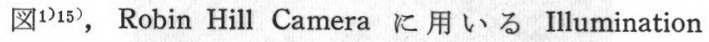
ratio (sky factor) diagram 16) はそれぞれ本論に护ける P-I 型，F-I 型の網目に近似なものである.しかし細 分割における経度のとり方が若干異なっておりまたい ずれも II型に相当する網目は考案されていない.

\section{6. 実 測 例}

一例として, 本校講堂における昼光率の算定結果を示 す.図 15 は講堂の概略図であり，A，B，C执よ゙D の各点は測定位置を示し, いずれも床上 $80 \mathrm{~cm}$ の机上面 で測定した。

図 16〜19 は凸面鏡による投影図，図 20～23 は魚眼 レンズによる投影図である。

表 8 算定値および計算値

\begin{tabular}{c|r|r|r}
\hline \multirow{2}{*}{ 測定位置 } & \multicolumn{2}{|c|}{ 昼 } & \multicolumn{1}{|c}{ 光 } \\
\cline { 2 - 4 } & 凸 面 & \multicolumn{2}{|c}{$(\%)$} \\
\hline $\mathrm{A}$ & 14.0 & 魚眼レンス & 計 算 值 \\
\hline $\mathrm{B}$ & 12.5 & 15.0 & 16.5 \\
\hline $\mathrm{C}$ & 1.6 & 13.0 & 15.6 \\
\hline $\mathrm{D}$ & 1.0 & 1.7 & 1.97 \\
\hline
\end{tabular}




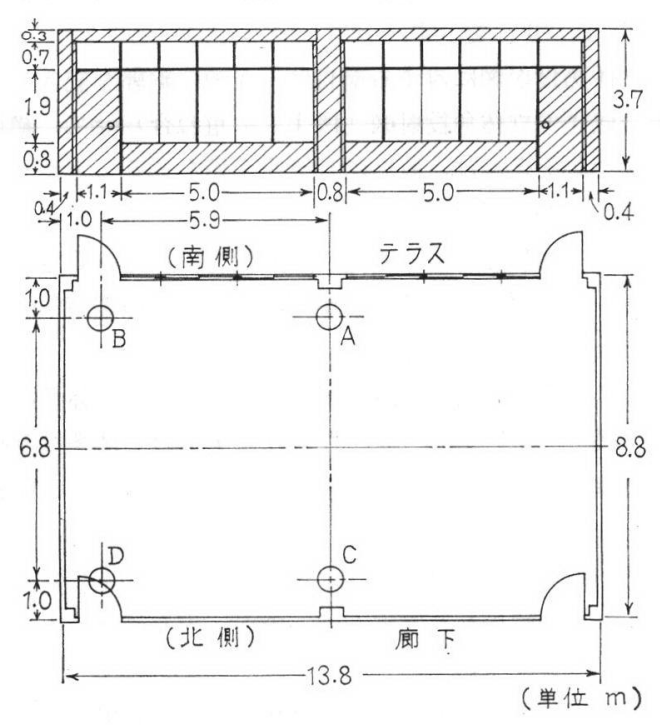

図 15 測定場所の概略図

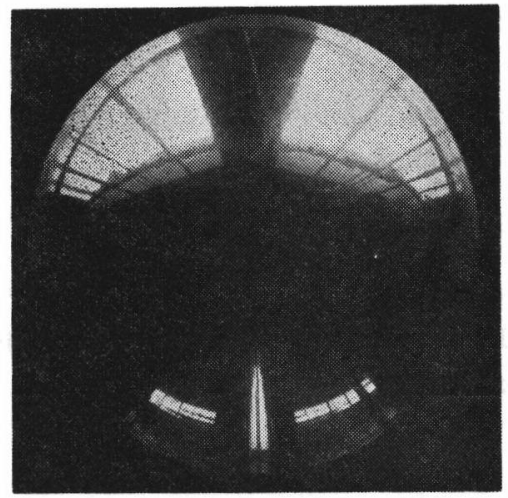

図 16 凸面鏡による投影図 (A点)

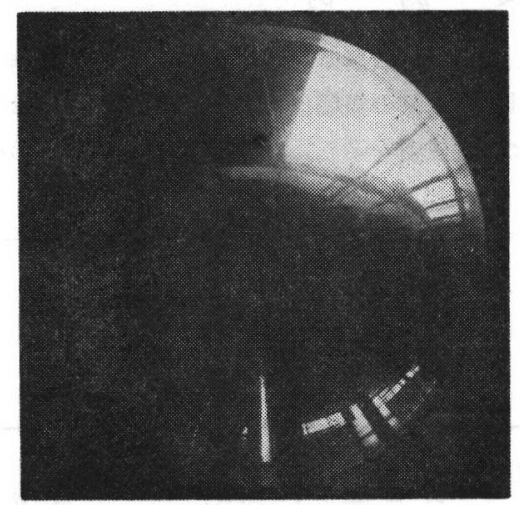

図 17 凸面鏡に上る投影図 (B点)

算定に際しては, 南側の空による直接昼光率だけ行な い(北側はくもりガラスになっており，また廊下がある ため) 網目はいずれも型を用いた。

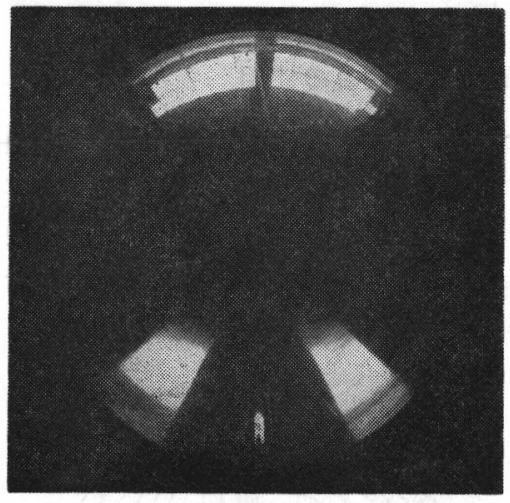

図 18 凸面鏡による投影図 ( C 点)

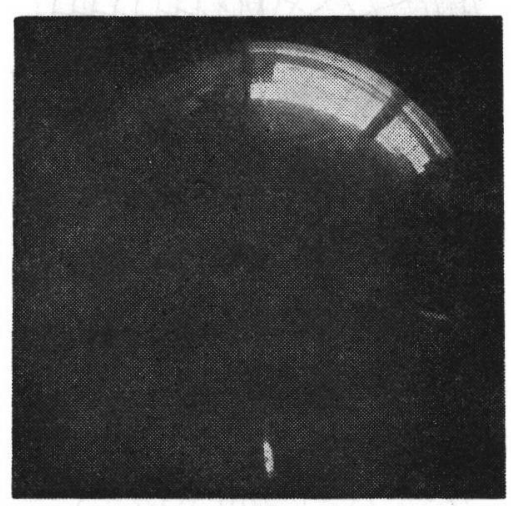

図 19 凸面鏡による投影図 (D点)

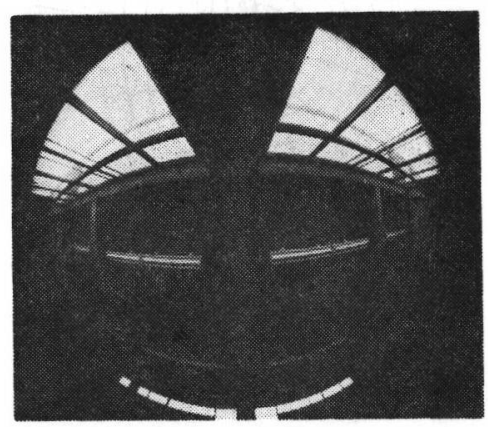

図 20 魚眼レンズによる投影図 (A点)

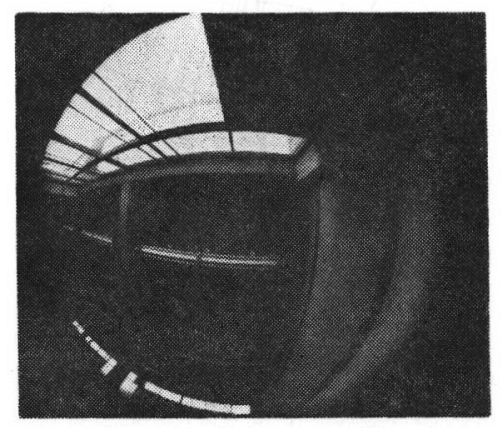

図 21 魚眼レンズによる投影図 (B点) 


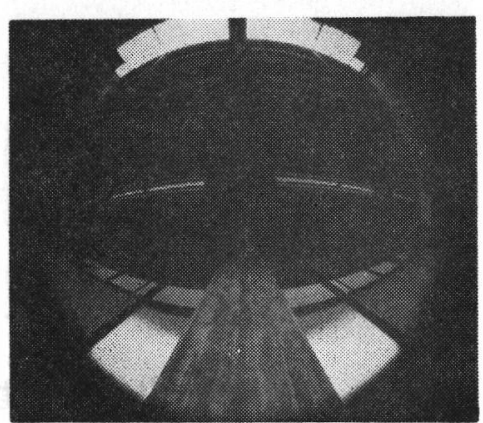

図 22 魚眼レンズによる投影図 (C点)

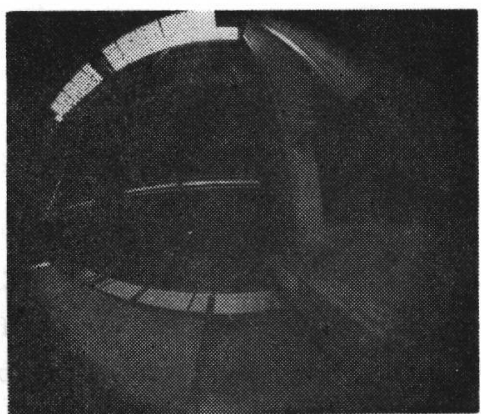

図 23 魚眼レンズによる投影図 (D点)

表 8 に上記算定值および直接計算により求めた結果 を示す．魚眼レンズによるもののほうが，凸面鏡よりよ い結果を得ているが，これには凸面鏡の精度の問題もあ ると思われる.

等昼光率網目は, いずれも円の周辺に近い部分が疎に なっているため， C, D 点のように天頂角 $\theta$ の大なる 光源の昼光率を求めるとき, 多少算定しにくい場合があ る.したがって，精度をよくするためにも，分割をるら 少し細かくする方法も考えられる.

凸面鏡および魚眼レンズによる昼光率算定は，直接計 算から求めるよりも迅速かつ容易であり, 一応本研究の 目的を達成し得た.

最後に, 終始ご指導ごベんたつを賜わりました本学生 産工学部長横地伊三郎先生に厚くお礼申し上げます。
参考文 献

(1) 日本建築学会：採光設計 (1963) 12,64

(2) 照明学会 : 照明のデータブックオーム社 (1958) 197

(3) H.Cotton : Principles of Illumination, Chapman \& Hall Ltd. (1960) 463

（4）小木曽 : 日本建築学会研究報告 No. 15 (1951)

(5) 関原・渡辺・小木曽 : 建築計画の研究（第一輯昼 光照明) 森北出版 (1949)

(6) P.F. O'brien : Pleijel's Globoscope for Lighting Design, Illum. Engng (1963) 132

（7）藤原・大谷：簡易立体角投射写真撮影装置につい て 日大理工学術講演会論文集 (1962) 141

（8）藤原・大谷：簡易昼光率計について 電気四学会 連大論文集 (1963) 1103

（9）藤原 - 大谷 : 等昼光率網目について 日大理工学 術講演会論文集 (1963) 153

(10) 藤原・大谷：等昼光率網目について 電気四学会 連大論文集 (1964) 977

(11) 藤原 - 大谷 : 昼光率の一測定法について 日大理 工学術講演会論文集 (1964) 139

(12) 藤原・大谷・後藤 : 魚眼レンズを用いた昼光率測 定法について 電気四学会連大論文集 (1965) 12 85

(13) 藤原・大谷・後藤 : 魚眼 レンズ 用等昼光率網目 （矩形空）電気四学会東海支部連大論文集(1965) 141

(14) 藤原・大谷・後藤 : 矩形空のための等昼光率網目 (魚眼レンズ用) 日大理工学術講演会論文集 (1965) 203

(15) 小木曽・武井：正射影型魚眼撮影装置「O T ス ープ」の考案 日本建築学会論文報告集 No. 119 (1966)

(16) J. Longmore : The Full Field Camera, The Photographic Journal 104-5 (1964)

（受付 1967 年 7 月 29 日 再受付 1967 年 9 月 25 日） 